Historic, Archive Document

Do not assume content reflects current scientific knowledge, policies, or practices. 


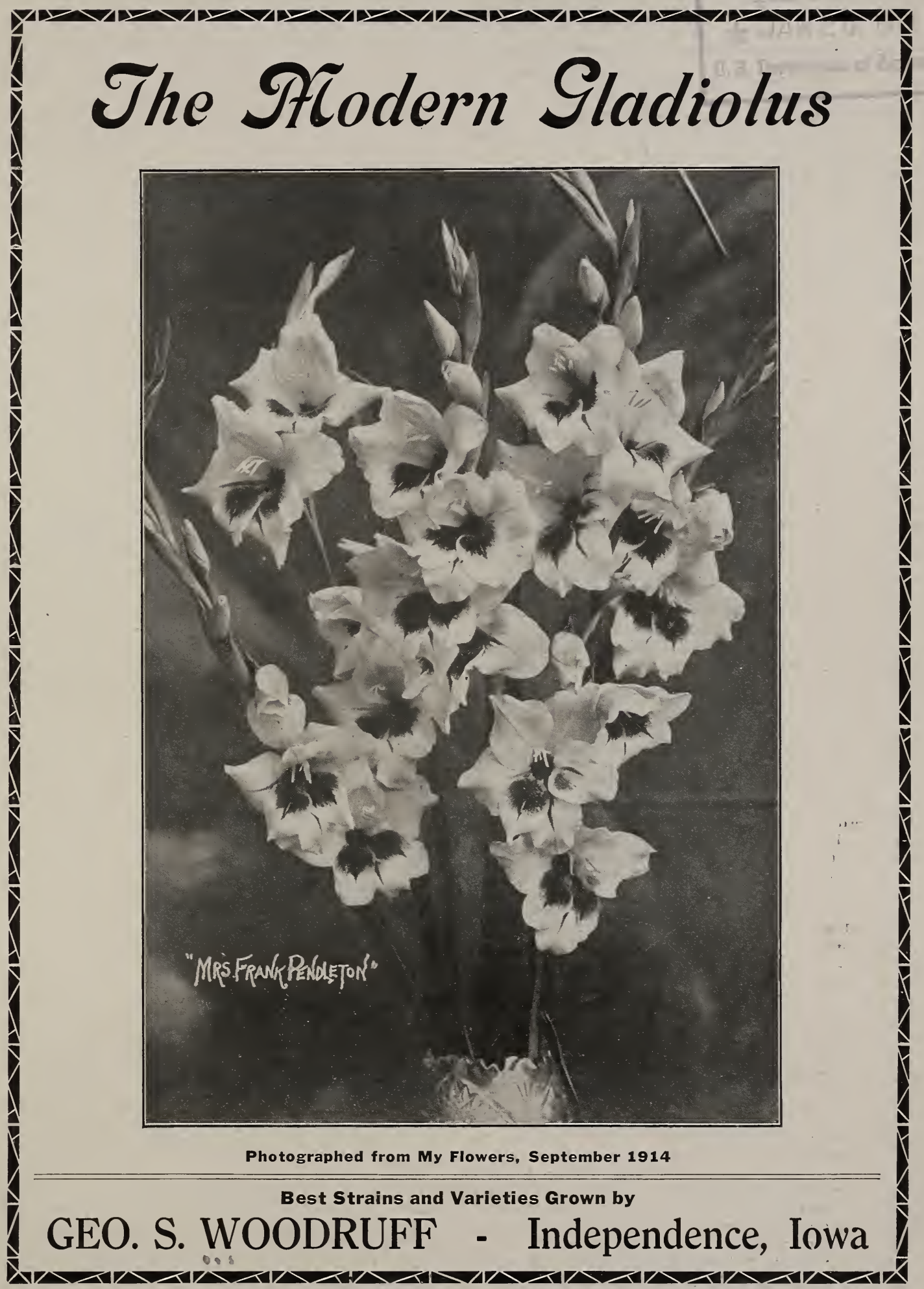




\section{THE MODERN GLADIOLUS}

\section{IIY CATALOG.}

It will not be as big as usual. Printer's wages are high; paper is "out of sight" and soaring. I have hitherto given quite a little history of the gladiolus, its origin, species, strains, etc., but the Modern Glodiolus has at last come to be pretty well known-thanks largely to us fellows who have, for love and money, taken large collections of flowers to the State and other fairs and spent weeks of long days keeping them fresh and in order and in answering questions, wise and otherwise. So I will cut that all out and proceed.

\section{How to Grow Good Gladioli.}

WHERE In any good soil, well prepared, tho a sandy loam with a clay subsoil is the best. Clay soils are not good; yet good gladioli can be grown in them if they are kept well cultivated and not allowed to bake down after rains. If you are obliged to use a clayey soil try to put some sandy loam in the furrow and cover shallow until well up. Plant in full sunshine, the vegetable garden being generally the best place, but don't plant against the south side of a house or among the roots of trees. Nothing grows well in such a place. Avoid contact with fresh manure. Better plow in the manure in the fall and use some wood ashes sometimes if to be had. If commercial fertilizers are used don't choose nitrates but use phosphates and bone meal.

When. Don't overlook this. If you have a good lot of bulbs (as you should) divide them into several lots and plant at different times; some as early as you can work the ground and some as late as June, so as to have a succession of bloom. The largest bulbs ("corms" is the botanical term) will flower first and some varieties will bloom much earlier than others-you will find out by experience-and this catalogue. Plant deep, from four to six inches, according to the size of the bulbs. Plant in rows far enough apart to work well, either by hand or horse; from 20 to 30 inches. Bulbs two to three inches apart in the row. Cultivate often, beginning before the plants are up. Don't let the ground get hard but hoe soon after every rain. In very hot, dry weather mulch with straw or hay. Try to avoid watering but if the ground is dry at planting time water them in; and if it be dry when the flowers begin to show color give the soil a good soaking by making a furrow near the row and filling it several times with water. Don't give a little sprinkle.

\section{Cut Flowers}

Cut the stem as soon as one or two flowers are open, leaving four or five good leaves to mature the corm, and let the flowers open in water in the house. Every day break off the old flowers, shorten the stem a little and change the water. So treated they will be fine for a week or ten days, especially if kept in a cool place at night. The very last flowers, when the stems get too weak, will make beautiful saucer bouquets with a little green foliage.
Harresting and Keeping.

Dig the corms before the ground freezes, cut off the tops at once (never mind what the books say about that) and dry well. Store in a cool place, safe from frost, in shallow boxes or crates. Do not cover with anything unless you are obliged to keep them in a rather warm cellar when they may be covered with dry sawdust or perfectly ary earth. Some kinds die down early and I prefer to dig such at once, as I think they are better out of the ground. I prefer to dig before the tops die as they dig easier. In digging loosen with a fork and pull up. Any time before spring pull off the old bulb and the cormels. I do this as soon after digging as I can get to it.

HOW T0 BUY. My advice to beginners, unless you have lots of money, is to buy from me an assortment so as to have a lot for your money and enough to divide into several plantings, as before recommended. These will not be a chance mixture but eacn lot made up separately, but without marks. At the same time order a few with names so as to be able afterward to know which to order. These will cost a little more than the same sorts in the mixture. You don't have to buy a dozen to get the dozen rate, but you had better take not less than two of a kind, to be sure.

\section{NAIED SORTS.}

It is difficult to keep a list down, as there are so many good varieties, but I am trying to do so and will leave out a number of good sorts which are not enough different from others to be worth while or of which I have not enough to be sure of filling orders. It is awkward to have to write back: "soid out." I will not substitute unless you give permission.

\section{PRICES, SIZES AND CARRIAGE.}

My prices are the lowest asked for first class stock. Our flowers take first premiums at State and County fairs whenever exhibited. Second and third size bulbs, if they are young, grown from the bulblet, are as good as first size except for the very late plantings. The largest will perhaps start a little stronger and flower a little earlier and have a little larger spike. Some of the choicest sorts never have large bulbs.

In order to avoid misunderstandings I list everything carriage prepaid. So, in comparing prices with others, please remember that some dealers list bulbs net, transportation to be paid by purchaser. When bulbs are ordered to be sent by express, collect, I send the larger bulbs and put in extras to cover express charges. I prefer to send by express where I can, but cannot reach all points and so must estimate at mail rates.

Parties living beyond the Fifth Zone (your postmaster can tell you) should add about $5 \mathrm{c}$ for each 50 bulbs to list price for extra postage and if more is sent than necessary, I will add bulbs to make it right. I always aim to do a little better than I advertise. 
Altho labor and everything entering into the cost of growing and preparing have advanced I have kept the price of most varieties down to the old level, but have advanced a few named sorts to bring them up to wholesale price and a little better.

\section{OAKWOOD MIXTURE.}

This is made up from all strains, such as gandavensis, Childsi, Lemoinei and Groff's Hybrids, which I am not offering separately, and will be found a very delightful mixture, including many varieties which have not been named.

\section{PRICES.}

F'rst Size, $1 \frac{1 / 2}{2}$ in. diameter; doz. $35 \mathrm{c}$; per $100 . \$ 2.75$ First Size, per 1,000 by express, not prepaid. . 29.00 Second size, 1 in. to $1 \frac{1}{2}$ in. per $100 \ldots 2.06 . .1 .75$ Second size, per 1,000 , not prepaid ........ 15.00 Third size, $1 / 2$ to 1 inch diameter, per $100 \ldots 1.00$ Third size, per 1.000 not prepaid ......... 7.00 25 at 100 rate; 250 at 1,000 rate.

If you want them sent by parcel post at the 1,000 rate add about $10 \mathrm{c}$ per hundred for 1 st size and about $5 \mathrm{c}$ per hundred for 2 nd size.

\section{SILVER TROPHY STRAIN.}

A special selection of named and unnamed sorts, divided into three color sections as follows:

Section 1. Finest reds, scarlets and crimsons, some with rich markings, prepaid, per doz. $40 \mathrm{c}$; per

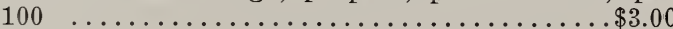

Section 2. New white, light pink and yellow, large size, in great variety of shades and with stains and blotches of rich colors; postpaid, per doz. $50 \mathrm{c}$; per $100 \ldots \ldots \ldots \ldots \ldots \ldots \ldots \ldots \ldots . \ldots \ldots$

Scetion 3. Rare "blues" in clematis, lilac and heliotrope shades, rare and but little known, per doz. $65 \mathrm{c}$; per $100 \ldots \ldots \ldots \ldots \ldots \ldots \ldots . \ldots 4.00$

All three sections mixed per $100 \ldots \ldots \ldots \ldots \ldots 3.00$

\section{NAMED SORTS.}

America-Well known, the most popular light lavender pink in the world. 6c each $60 \mathrm{c}$ per doz.

Amethyst-(No. 114). Large flower of old rose, with large white center. $10 \mathrm{c} ; 75 \mathrm{c}$ doz.

Annie Wigman-Pale yellow with small red blotch; good, erect habit. Very good 7c each; 70c per doz.

Attraction-Large, well opened flower of rose crimson, wide pure white throat, a good grower and one of the best, 8c each; 80c per doz.

Autuma Queen.-See "Lillian."

Augusta-Still the leading commercial white. Often tinted lavender; of the gandavensis type, erect, often with 3 or 4 branches, nearly the whoie spike open at once. $5 \mathrm{c} ; 50 \mathrm{c}$ per doz.

Baltimore-(Formerly called Salmon Queen.) Fine wide flower salmon with dark red-brown blotch. Very showy, singly or in masses. 10c each $\$ 1.00$ per doz.

Baron Hulot-The finest clear, dark, violet blue, small yellow bands. Medium size; $8 \mathrm{c}$ each; $80 \mathrm{c}$ per doz.

Berkshire-Large, well opened flower. Delicate shade of pink, penciled with dark pink in throat, which is margined straw and dotted red. Exquisite. $15 \mathrm{c}$ each. $\$ 1.50 \mathrm{doz}$.
Bernice-(No. 111) Tawny yellow with pink shadings; many open at one time. Early. 6 c each. $60 \mathrm{c}$ doz.

Bertrex--(Austin) White with lilac shading in the throat; size and form of America. Spike tall, straight, sometimes branching. Might be called a "White Schwaben." Increases rapidly and forces well. Awarded Silver Cup as "best new seedling" at Cleveland, 1913 15c each. $\$ 1,50$ doz.

Blanche-I have dropped this. Not satisfactory.

Blue Jay-(Groff's) The true variety; not Baron Hulot which was at one time sold under this name. Tall, strong plant. Flower wide open, light blue with white and maroon throat. Finest of this color. 25c., $\$ 2.50$ doz.

Burrell-(Napoleon-(W) Dark red, large flower and compact spike. Handsome butterfly markings. Robust habit and a good increaser. Excellent. 8c; $75 \mathrm{c}$ doz.

Black's Early Pink-(A Nanceianus) Flower nearly as large as Mrs. King and similar in shape and arrangement on the stem; salmon pink, not rose, with dotted markings. Early as Halley. 5c each; $50 \mathrm{c}$ doz.

Brenchleyensis-An old variety but still in demand for mass of color. Rich vermilion scarlet in long spike, all open at once $5 \mathrm{c}$ each. $50 \mathrm{c}$ doz.

Canary Bird-(gandavensis) A clear yellow of good size and fine trusis. Fine to use with Baron $\mathrm{Hu}-$ lot. $10 \mathrm{c}$ each, $\$ 1.00 \mathrm{doz}$.

Candidum $_{\vdash}$ (Austin) Large white blooms; tips of petals tinted and somewhat reflexed like a lily. Erect, free bloomer. $10 \mathrm{c} ; \$ 1.00 \mathrm{doz}$.

Cattleya-(Austin No. 2) Lilac rose, with deep pink blotch, round flower, tall spike, early. $10 \mathrm{c}$ each, $\$ 1.00$ doz.

Charlemagne-(Lemoine) Giant type with very large, open flowers on massive spikes; sunrise red, flaked darker and marked with large, creamy, white blotch, densely spotted with purple carmine, $15 \mathrm{c}$.

Cheerful-(W) Upright, bright rose pink; white face. $5 \mathrm{c}$ each. $50 \mathrm{c}$ doz.

Chicago White-Tall spike and good medium-size flower. White with small lavender lines in lower petals. Many think this is the coming white for florists. Certainly fine. Early $5 \mathrm{c} ; 50 \mathrm{c}$ doz.

Columbia (Ch)-Light orange-scarlet, freely blotched and penciled with bluish-purple. Throat freely mottled. Large 10c; $\$ 1.00$ doz.

Cracker Jack-Large flowers of rich velvety dark red; throat spotted yellow and dark maroon. 10c each, $\$ 1.00$ per doz.

Distinction-Similar in color to Goliath, spike taller, flower a little smaller but flatter open. Good. Stock scarce, $15 \mathrm{c} ; \$ 1.50 \mathrm{doz}$.

Eldorado-Medium sized deep, clear yellow; lower petals spotted maroon and black. Early. 10c each $\$ 1.00 \mathrm{doz}$.

Empress of India-Very dark maroon, almost black; buds like satin. Very distinct; early. 10c each; $\$ 1.00$ doz.

Electra--Very large and tall. Soft vermilion scarlet with creamy stripe on lower petals. Recelved first class certificate at London and Haarlem. $15 \mathrm{c}$ each, $\$ 1.50$ doz.

Elizabeth Kurtz-(Pfitzer) Pure white. Large flowand strong grower. $10 \mathrm{c}$ each, $\$ 1.50 \mathrm{doz}$. 
Europa-(Pfitzer) Large round flower of the purest white on fine straight spike. Several open at one time. Unquestionably the finest pure white in commerce. Requires good soil and plenty of moisture. doing best in the fall. $15 \mathrm{c}$ each. $\$ 1.50 \mathrm{doz}$.

Evaline-(Smoky Violet) (W) A large, well opened flower. Color violet underlaid with terra cotta red. Variable. Very rich and striking. $10 \mathrm{c}$ each, $\$ 1.00$ doz.

Evelyn Kirtland-(Austin) "It is diffcult to describe in words the beauty of this variety. The flowers, of strong substance, are a beautiful shade of rosy pink, darker at the edges fading to shell pink at the center, with brilliant scarlet blotches on lower petals. Entire flower showing a glistening sparkling luster. The form is wide open, somewhat reflexed, slightly fluted and many open at one time. Spike giant in height, straight but slender and bending gracefully with its burden of blooms. Wonderfully decorative."

Winner of the Chas. F. Fairbank prize in "Best Display New Seedlings," Cleveland, 1915. Also received Award of Merit from Gladiolus Society of Ohio, $20 \mathrm{c}, \$ 2.00$ doz.

Faust-Erroneously named. See "Geo. Paul."

Geo. Paul-(Harvard) Very large maroon flower, slightly stained yellow. $10 \mathrm{c}$ each. $\$ 1.00$ doz.

Gil Blas-Charming early bloomer of dwarf habit. Flowers salmony rose with fire red blotch, on straw colored ground, $10 \mathrm{c}$.

Glory of Holland-Of Dutch origin. Pure white with exception of faint pink tint in throat, good grower. Award of Merit at London and Haarlem. 10c each, $\$ 1.00$ doz.

Golden Wedding-(Ruff) One of the really superior hybrids of Primulinus, which has made a great hit in the St. Paul cut flower trade. Clear yellow on a good stem. A bunch of these with a few Baron Hulot is a thing of beauty. $10 \mathrm{c}$ each. $\$ 1.00 \mathrm{doz}$.

Golden King-This variety, offered to the pubic in 1912 , is still the best blotched yellow, as far as I know. It is a strong grower and multiplies well. Color a clear, unfading yellow witha vivid crimson blotch in throat, the flowers large and well opened, of good substance, often twenty to twenty-three on a spike, neither crowded nor too far apart. The flowers are sometimes double, having from eight to eighteen petals instead of the usual six. Awarded First Class Certificate by the National Gladiolus Society of England. 10c $\$ 1.00$ dozen.

Gretchen Zang-(Austin) Flowers large and sparkling and the most beautiful soft meiting shade of pink blending into scarlet on lower petals. Spike tall and graceful. A prize winner. $15 \mathrm{c}, \$ 1.50$ doz.

Golden West-Rich nasturtium red, with a golden suffusion, lower petals tipped with yellow. Fine and rare. $10 \mathrm{c}, \$ 1.00$ dozen.

Goliath-(Holland) Extremely large, dark wine colored flower. Called "dark violet" which it is not but very fine indeed. $20 \mathrm{c}$., $\$ 2.00 \mathrm{doz}$.

Halley-Very large, wide open flower of delicate salmon pink. The lower petals have a creamy blotch with narrow lines of bright red. Very early and a great acquisition. Awarded First Class Certificate and very popular. $8 \mathrm{c}$ each, $80 \mathrm{c}$ doz.
Herada-(Austin) Very new and distinct "Blooms of inmense size on tall, straight spike. Pure mauve with deeper markings in throat. Winner of First Prize. 'Size of bloon and spike only to count.', $15 \mathrm{c}$ each, $\$ 1.50$ doz.

Hyde Park-(Gand) A cross between the o:d favorites, May and Shakespeare. Large, open flower, upper petals white, penciled and feathered rose; lower petals distinctly blotched with cream. Foliage clean and healthy, remaining green until frost. Very early bloomer. Certificate of Merit American Institute, $1913,10 \mathrm{c}, \$ 1.00$ doz.

Ida Van-Large, open flowers, lily-like, solid bright red to flaming pink, with darker shade of red in lower petals. First premium at Cleveland, 1913, for best red. Award of Merit National Gladiolus Society of England, 1913, 10c, $\$ 1.00 \mathrm{doz}$.

Independence-(W) All things considered, the best light red in market under name. Strong upright grower, clean foliage, large cherry flower of perfect shape, marked white and maroon in throat, and on good spike. Stem always straight. Fine by artificial light, $5 \mathrm{c}, 50 \mathrm{c}$ dozen.

Intensity-One of the very fine ones. Large bright scarlet, lower petals spotted with white. $10 \mathrm{c}$ each. $\$ 1.00$ doz.

Jean Dieulafoy-One of the indispensable sorts. Very wide creamy white flowers with lower petals of blotched maroon. Lasts long as a cut flower, $10 \mathrm{c}$, $\$ 1.00 \mathrm{doz}$.

Kunderd's Glory-Widely celebrated as the first of a new ruffled strain. Each flower ruffled and fluted. Stalks robust with from eight to twelve flowers light cream with small crimson stripe. $10 \mathrm{c}$ each

Jessie-Rich velvety red; small yellow line in lower petals; long spike of well-opened flowers; early. An improvement on Brencheyensis, $10 \mathrm{c}$.

Klondike-Good truss and good grower; round, well opened flowers of primrose yellow with blotch of crimson-maroon on lower petals. Well known; but Miaude is better, $5 \mathrm{c}, 50 \mathrm{c}$ dozen.

Lily Lehman-Extra fine lily-formed flower, generally pure white with very faint lemon tinge (no blotch) in throat. Sometimes faintly tinged pink. Often has two or three branches and is very early. $10 \mathrm{c}, \$ 1.00$ doz.

Liebesfener-(Holland) Extra fine dark scarlet, without markings. The introducer calls it the finest red "what consists" to date. Award of Merit London and Haarlem. Certainly fine. .15c, $\$ 1.50$ per doz.

Loveliness-Very large wide open flowers of palest cream suffused apricot in throat. Flowers well placed on straight spike and 10 to 15 open at once, $15 \mathrm{c}, \$ 1.50$ doz.

Lilian-Introduced by me under this name about 10 years ago and so listed in Cornell College bulletin, but lately much advertised in trade papers under the name of "Autumn Queen." One of my introductions from Groff's Silver Trophy. Greatly admired at state and county fairs. Strong grower with heavy stem and wide, drooping foliage. Flower in Jean Dieulafoy style, nearly white ground with light scarlet spot in lower petais. $15 \mathrm{c}$ each, $\$ 1.50$ doz.

Mad. Monneret.-Delicate salmon rose. Gandavensis type, good spike; late bloomer. $5 \mathrm{c}$ each, $50 \mathrm{c}$ doz 
Mrs. Francis King-(Coblenz) Long spike of immense flowers of Nanceianus form, light scarlet or flame red, shaded salmon. Most popular scarlet. Spike often branched and somewhat curved, gracefully. $5 \mathrm{c}$ each, $50 \mathrm{c}$ doz.

Maude-One of the good light glads. Growth upright with narrow, straight leaves. Flowers medium or light yellow with rich maroon spot in lower petals. $10 \mathrm{c}$ each, $50 \mathrm{c}$ doz.

May-(Gand) An old stand-by. Lovely white flower, finely flaked rosy crimson. Strong spike, good forcer, $5 \mathrm{c}, 60 \mathrm{c}$ doz.

Meadowrale-Excellent for florists. Pure white ground. A touch of vivid crimson in the throat, with line of faint pink in three lower petals. Later than Chicago White and a purer white ground. $8 \mathrm{c}$ each, $80 \mathrm{c}$ doz.

Minnesota-One of the best florist's light. Strong grower and early. A strong, long spike of wellopened flowers of pale cream with very small maroon spot. Productive and blooms from very young bulbs. Two or three weeks earlier than America. $5 \mathrm{c}, 50 \mathrm{c}$ doz.

Mrs. W. E. Fryer-(K) Fine large scarlet. Ta!l, extra strong grower; somewhat like a magnified Mohonk. $15 \mathrm{c}$ each, $\$ 1.50 \mathrm{doz}$.

Mrs. Frank Pendleton, Jr, (See front cover) A remarkable flower which has been likened to a big gloxinia. Very large flowers of delicate pink with large blotch of blood red. Will flower from very small corms. Award of Merit I ondon 1913; First Class Certificate Am. Glad. Society 1911; Ditto Mass. Hort. Society 1911. 10c each, $\$ 1.00$ doz. $\$ 8$ hundred.

Mrs. G. W. Moulton-(K) Tall spike of large magenta crimson, American Beauty color, with darker marks on lower petals. A gorgeous thing in the field or as cut flower. Greatly admired at state and other fairs. $25 \mathrm{c}$ each, $\$ 2.50 \mathrm{doz}$.

Mrs. Watt-Brilliant wine red. Fine flower and spike; vigorous and productive. $10 \mathrm{c}, \$ 1.00 \mathrm{doz}$.

Myrtle -(Kunderd) A beautiful flower. Light pure pencilled rose. A gandiavensis variety and a great favorite with the cut flower trade. Whole spike open at once. $10 \mathrm{c}, \$ 1.00$ doz.

Niagara-(Banning) This new yellow has created a sensation and received Certificates of Merit from Masaschusetts Horticultural Society and Dutch Bulb Society at Haarlem, Holland, 1911. Open class ward American Gladiolus Society Chicago, 1912, for the best yellow. A class by itself. A rich cream combined with canary yellow, sometimes mottled paile pink. Large, thick flower on strong, tall stem. Very distinct, $10 \mathrm{c}, \$ 1.00 \mathrm{doz}$.

Orion-Peculiar shade of brownish red, with small yellow markings, $5 \mathrm{c} 50 \mathrm{c}$ doz.

Parama-A seedling of America but a much deeper rose pink. Very large and solid. First Class Certificates everywhere in Europe and America. Later than America. $10 \mathrm{c}, \$ 1.00$ doz.

Peace-(Groff's) This is a most magnificent variety, the finest of a:l whites. Though it has a delicate lilac spot on lower petals, the ground color is of the whitest white and the petals firm and solid. Flowers are large, well opened and borne on tall strong spikes. Lasts well in water and a:l buds open. Fine clean foliage. Late bloomer. Formerly sold largely at $\$ 1.00$ each, $10 \mathrm{c}, \$ 1.00$ dozen, $\$ 7.00$ hundred.
Pink Beauty-(Van Toll) Rose pink with darker blotch. Long spike, very early, 5c, 50c dozeĩ.

Pink Perfection-A remarkable variety from Holland. First Class Certificate Londan and Haariem, 1913. I find it splendid. Lovely light pink; flowers large, uprards of twenty buds closely set on long stem, six or eight flowers open at once and buds showing color, like rose buds, stems often curved, $10 \mathrm{c}, \$ 1.00$ dozen.

Pink Progression-A sport from Pink Beauty and as early. Pale rose with darker blotch. Long spike. $5 \mathrm{c}, 50 \mathrm{c}$ dozen.

President Taft-De'icate pink, red blotch, light line through each petal. Buib, flower and spike large. Late. Fine, 5c, 50c doz.

Prince of Wales-A new salmon variety that is making a sensation. It is early, like Halley, but a clearer salmon, more yelowish and without the throat markings. It increases rapidly and b'ooms a perfect bouquet, even from small bulbs; has bean known to bloom from the bulblet. $25 \mathrm{c}$ each, $\$ 2.50$ doz.

Princepine-(Kirchoff) A seedling of Princeps and an improvement in some respects. More flowers are open at a time and, though not quite so large, they are even brighter in color and have very beautiful and conspicuous white throat markinzs. Plant consideraby taller and foliage lighter green, $10 \mathrm{c}, \$ 1.00 \mathrm{doz}$

Princeps-(The Amaryllis Flowered) Largest crimson scarlet, flat opened, white blotches in lower petals. Broad foliage, $8 \mathrm{c}$ each, $80 \mathrm{c}$ doz.

Prophetesse-Round, pearl white with crimson throat. Early $7 \mathrm{c}, 70 \mathrm{c}$ doz.

Premiere-(The First) Creamy white, fainty furfused with crimson; crimson blotch on lower petals; spike tall, 6 or 8 flowers open at one time. Blooms early, 75 days from planting, 10c.

Primulius -A distinct new species from South Africa. Clear primrose yellow, somewhat hooded in form, arranged separately on slender but firm stem. Has been used for crossing with other yellows, $15 \mathrm{c}$.

Primulinus Hybrids-Seedlings from the Primulinus, showing great variety of shades, mostly different shades of yellow and blush, some wider open than the parent, less hooded and often larger, but all showing strongly the same general characteristics of gracefulness and delicacy. All very early bloomers and very dainty. $10 \mathrm{c}$ each. $75 \mathrm{c}$ per doz.

Primuliuus Hybrids of Golden King.-This special strain, originated here, consists of seedlings of Golden King, pollenized with Primulinus.

They get from Golden King increased size and more open flowers and slight throat markings. Some of them are very fine. $10 \mathrm{c}$ each $\$ 1.00$ per doz.

Procerpine-A handsome bright rose color of good size and habit which I got from Holland last year. Try it. $15 \mathrm{c}, \$ 1.50 \mathrm{doz}$.

Queenly-Introduced by me and, tho I found it among the Silver Trophy sorts, I have never seen it elsewhere. A most delightful flower; round pearly almost white; firm and waxy, deilicate spot of faint lilac in throat, most beautifu'ly arrarged on the stem, which, tho slender, is firm and round. A fine cut flower sort. $13 \mathrm{c}, \$ 1.00 \mathrm{doz}$.

Qucen Willelmina-Very heautiful large open flower of del cate apple-blossom pink with paie blotches on lower petals. Extra good; makes a mass of flowers in the row. $15 \mathrm{c}, \$ 1.50 \mathrm{doz}$ 
Rosella-Large light rose, wide open and flat, with white throat. A universal favorite. $15 \mathrm{c}, \$ 1.50 \mathrm{doz}$.

Red Emperor-Said to be the same as Dominion. "Truly regal. "Very large, open flower, rich dark scarlet, tall spike. Very early. 20c each, $\$ 2.00$ doz.

Rose Wells-(Austin) Large, wide open blooms; light clear rose color with small attractive blotch of lilac rose and yellowish green. Vely tall, branching spike, slender and graceful. $15 \mathrm{c}, \$ 1.50$ doz.

Rouge Torch-(113) Very large white flower with scarlet Ieather in lower petals. S.ender stem, $10 \mathrm{c}$.

Schwaben-(Pfitzer) A grand yellow gandavensis which has received medals and certificates and has attained great popularity. Very robust growel and has a very large flower head; not so deep a yellow as Golden King. but has a much less conspicuous blotch. $10 \mathrm{c}$ each. $\$ 1.00 \mathrm{doz}$.

Scarlet Telret-I am gaad to be able to offer again this fine sort, first introduced by me, but "Lost awhile" Large flower, rich dark scarlet with slight shade of yellow in throat. $10 \mathrm{c} \$ 1.00 \mathrm{doz}$.

Sativiation-This is a variety which I have been growing under number for several years and consider one of the best light sorts. It is a strong grower and good multiplier. Long spike; flower's creamy white or yellow with handsome Lemo:ne markings. I marked it " $2-8,10,11$ " and one of my customers to whom I sold it as a sample wrote "It suits me to a T." $10 \mathrm{c}$ each. $75 \mathrm{c}$ dozen.

Scarsdale-Immense lavender pink, shaded dark rose. Unique. $10 \mathrm{c}, \$ 1.00 \mathrm{doz}$.

Sulpliur King-(Gand) Generally conceded to be the best clear yellow yet introduced. Long spikes of good sized flowers. 20c, $\$ 2.00 \mathrm{doz}$.

Tango-(Hoeg) Rich deep crimson carmine with darlier throat. Flower large. Plant tall and strong $15 \mathrm{c}, \$ 1.50$ doz.

Titanic-(Dr. Hoeg) This grand and unique variety is pronounced by most discriminating judges the finest nove'ty in dark colors for several years. It has been tried on a large scale by amateurs, but I purchased practically the entire stock from the originator. Exhibited at the Cedar Valley Fair in 1916 and 1918 and at the Iowa State Fair in 1917 and 1918 , it made a sensation. It is a robust growel and increases well, stem erect, flowers large, flat open. of a "lilac purple" or magenta crimson color, without throat markings but a white line through center of lower petals. I make the price low for such a variety. 20c each, $\$ 2.00$ per dozen.

111-Tawny yellow with pink shadings. Early (Bernice.) $6 \mathrm{c} 60 \mathrm{c}$ doz.

112-Yellow with long red blotch. Excellent, 5c. Deserves a name. Please suggest one.

Velvet King-(Calied also W. M. Mason, and 312,) Not so vely velvety, but a splendid, wide open, dark scarlet, veined on lower petals, with dark color. Vigorous grower and makes a fine show in the row. One of the best. $10 \mathrm{c}, 75 \mathrm{c}$ dozen.

War-Deep blood-red, shaded crimson-black. Tall erect. late bloomer, So!d for some time at $\$ 1.00$. $15 \mathrm{c}, \$ 1.50$ doz.

Willy Wigman-(Dutch) Creamy white, flushed soft pink, crimson blotch on lower petals, very pretty. First Class Certificate, $10 \mathrm{c}, 75 \mathrm{c}$ doz.

White Excelsior-(Rene de L'Anjou) Similar to Augusta, but pure white. Very straigt, tall and strong. $10 \mathrm{c}, \$ 1.00$ doz.

\section{SPECIAL OFFER}

of Mrs. Austin's varieties with Titanle

Evelyn Kirtland 25c, Bertrex 15c, Gretchen Zang $15 \mathrm{c}$, Herada $15 \mathrm{c}$, Titanic $20 \mathrm{c}$ All five, postpaid, for 65 cents.

Diener's New strain-Richard Diener of California, claims to have discovered a law in hybridizing by which he can double the size of any flower after one cross. I will not be responsible for the correctness of this claim but at the Panama Pacific Exposition he made an exhibit which received the highest praise from the correspondent of the Florists' Exchange. These and later additions were offered in 1917 at very high prices which were greatly reduced in 1919. But by this time trials of some varieties were so satisfactory that he has been obliged to raise the price materially. I have tried some of the lower priced sorts and the mixtures and, while the unnamed ones are not all equally good, some of them are remarkable in size and beauty and I recommend them for trial. They are rank growers and should be given rich soil and thoro cultivation. I offer the following:

Anna Eberius-(No. 10) The most popular of all I have offered. "Dark, veivety Nell Rose;" throat deeper. Flowers very large and spike long and straight. Extra fine and unique. .Great keeper. $25 \mathrm{c}$ each, $\$ 2.50$ per doz.

Capt. A. C. Baker-(No. 164) Rich, velvety red with darker center. Awarded Silver Medal at P. P. I. E. for best of all reds shown, $10 \mathrm{c}$.

Thos. T. Kent-(130) Rose pink, with deep ruby running thro center of each petal. Immense flower and long spike. "Flowers six inches in diameter" (sometimes;) spikes five or more feet high. Very substantial. Price advanced to 50c each; $\$ 5.00$ doz.

Mrs. Wm. Kent-(No. 1) Light fawn to ashes of roses, old rose throat. F:owers five inches diameter, heavy. Extra fine by test. $50 \mathrm{c}, \$ 5.00 \mathrm{doz}$.

Iyrtle McNal!y-(No. 19) Ruffled heavily. Medium tall. An improved "Glory" $10 \mathrm{c}, \$ 1.00 \mathrm{doz}$.

San Anselmo-(No. 22) An immense tall white, slightly striped. Fine for cut flowers. 50c.

American Beauty-(No. 23) Brilliant American Bea. ty color, with creamy yellow throat. Many flowers open at one time. "Flowers 66 to 7 inches diameter.” Beautiful. $\$ 1.00$.

Adeline Kent-(No. 136) Delicate light rose pink etc. Heavily ruffled from edges to center. Very fine indeed. $50 \mathrm{c}$.

Mary S. Burke-(No. 188) Canary yellow, overlaid with apricot. Deep canary center. (I shorten description.) One of the finest yellows known so far. Long spike. Price advanced to $\$ 1.00$.

The following I have tried in a small way and will recommend but can't give room for descriptions-which, after all, are very inadequate. writing.

In ordering any of these use numbers to save

Sarah Lillie-(No. 4) Lavender and ruby, $15 \mathrm{c}$.

Pres. Moore- (No. 31) Salmon pink. Mottled and striped, $25 \mathrm{c}$.

Fairfax-(No. 32) Solid magenta light yellow throat. Big and fine, $15 \mathrm{c}$. 


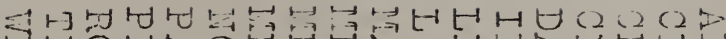

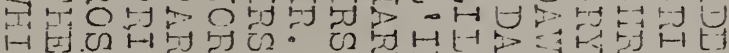

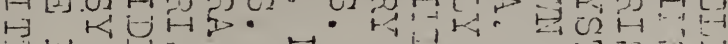

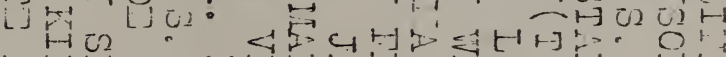
$\Rightarrow$ F⿱ O J

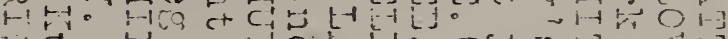

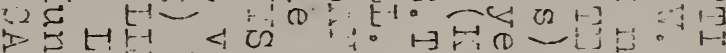

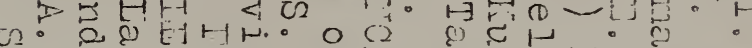

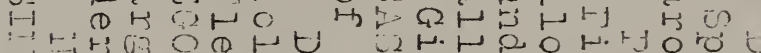

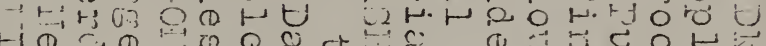
(1)

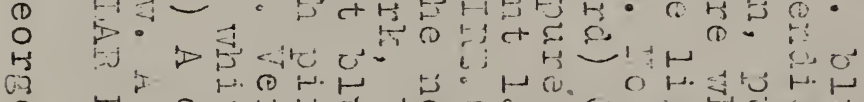
年

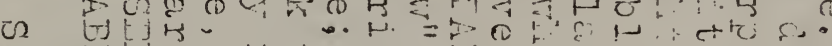
H故 - $]$ U - 1 1 H

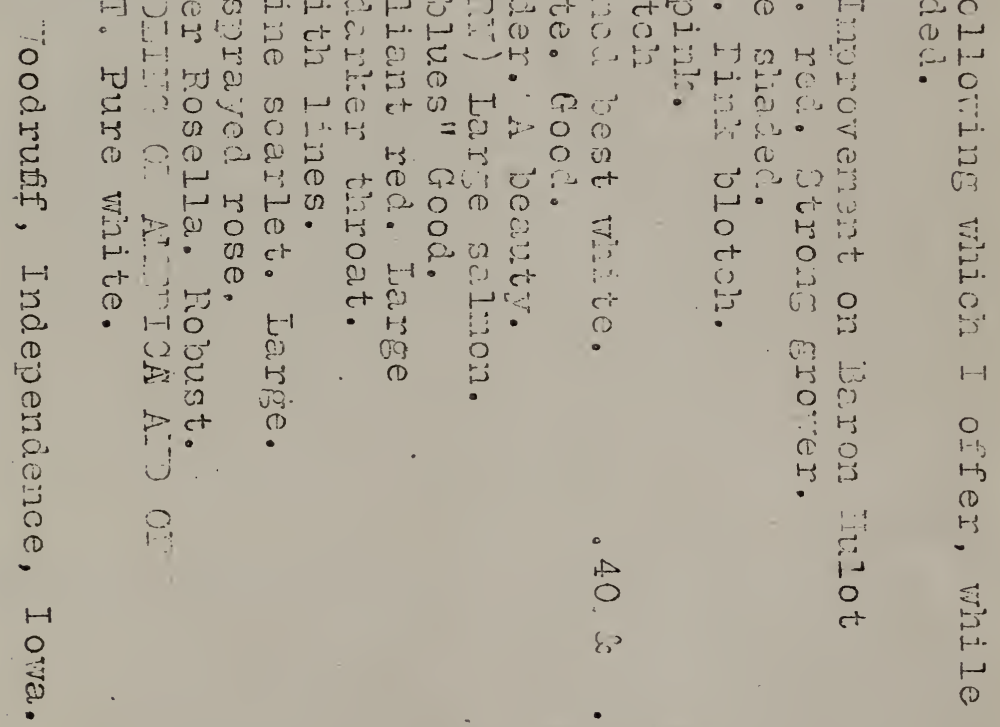

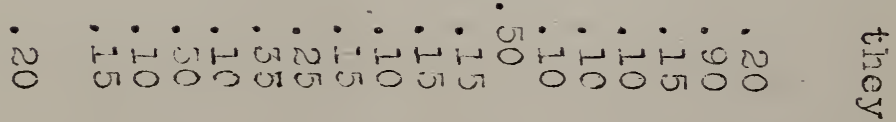

is 10

H. $\vec{x}$

(j) 0

(घ) त्

ㄴ

(1)

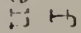

$\mathrm{DO}$

, 1.

$-$

is.

娄

i.

a.

$1-1$

$\underset{1-1}{0}$

(D)

这

1 
Rosella-Large light rose, wid white throat. A universal fi

Red Emperor-Said to be the "Truly regal. "Ver'y large, 0 : scarlet, tall spike. Very early

Rose Wells-(Austin) Large,

light clear rose color with s1 of lilac rose and yellowish branching spike, slender anc doz.

Rouge Torch-(113) Very larg scarlet feather in lower peta

Schwaben-(Pfitzer) A grand which has received medals has attained great popularity er and has a very large flow a yellow as Golden King, but spicuous blotch. 10c each. $\$ 1$

Scarlet Velvet-I am gad to b this fine sort, first introduce awhile" Large flower, rich slight shade of yellow in thrc

Satisfaction-This is a variety growing under number for se sider one of the best light si grower and good multiplier. creamy white or yellow witl: markings. I marked it " $2-8$, customer's to whom I sold it "It suits me to a T." $10 \mathrm{c}$ each.

Scarsdale-Immense lavender rose. Unique. $10 \mathrm{c}, \$ 1.00$ do:

Sulplur King-(Gand) Generall best clear yellow yet introdu, good sized flowers. 20c, $\$ 2.0 \mathrm{C}$

Tango-(Hoeg) Rich deep cri darker throat. Flower large. . $15 \mathrm{c}, \$ 1.50 \mathrm{doz}$.

Titanic-(Dr. Foeg) This granc is pronounced by most discri finest nove'ty in dark colors has been tried on a large sce I purchased practically the e: originator. Exhibited at the ( 1916 and 1918 and at the Iow and 1918, it made a sensation. er and increases well, stem flat open. of a "lilac purple" color, without throat markin through center of lower petal low for such a variety. $20 \mathrm{c}$ e:

111-Tawny yellow with pink sł nice.) $6 \mathrm{c} 60 \mathrm{c}$ doz.

112-Yellow with long red blotc Deserves a name. Please sug

Velret King-rCal:ed also W. I Not so very velvety, but a s dark scarlet, veined on lowe; color. Vigorous grower and $\mathrm{m}$ the row. One of the best. 10c

War-Deep blood-red, shaded erect, late bloomer, So!d for $15 \mathrm{c}, \$ 1.50$ doz.

Willy Wigman-(Dutch) Creamy pink, crimson blotch on lower First Class Certificate, 10c, 7:

White Excelsior-(Rene de L'An gusta, but pure white. Ver. strong. $10 \mathrm{c}, \$ 1.00 \mathrm{doz}$. 


\section{Some of the people who have grown Louise or seen it in bloom have expressed themselves as follows:}

Dr. J. H. NeEley, of Paulding, Ohio: "I think your variety Louise superb and fine. Sure going to be a winner. The flower in form and color is so near a Cattleya Orchid."

Mrs. R. W. Walters, Springfield, Ohio: "I never saw another like it and the velvety blotch is as rich as that of Pendleton."

Mrs. J. C. Grossman, Wolcottville, Ind.: "Louise is one of the grandest flowers I ever saw. Bright in color, large and massive, the peculiarly ribbed petals give it a fine appearance. It attracted more attention from visitors than any flower in our garden. The dry hot weather did not check it from producing fine large blooms. It is certainly wonderful."

C. R. Hinkel: "Why don't you show Louise at the big show? I think it ahead of any in its class. Growers will make no mistake to secure a start in this variety. When you look at my photograph, imagine a flower like it in form and color but 6 and 7 inches in diameter. Just take out the rule and measure two inches on the width and see where it would go to."

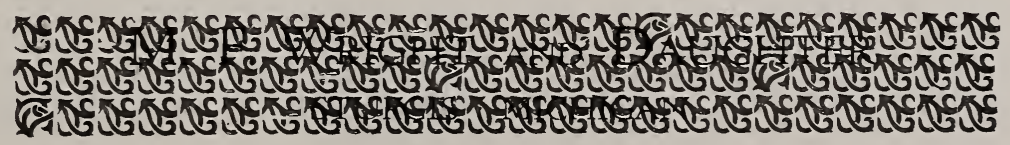




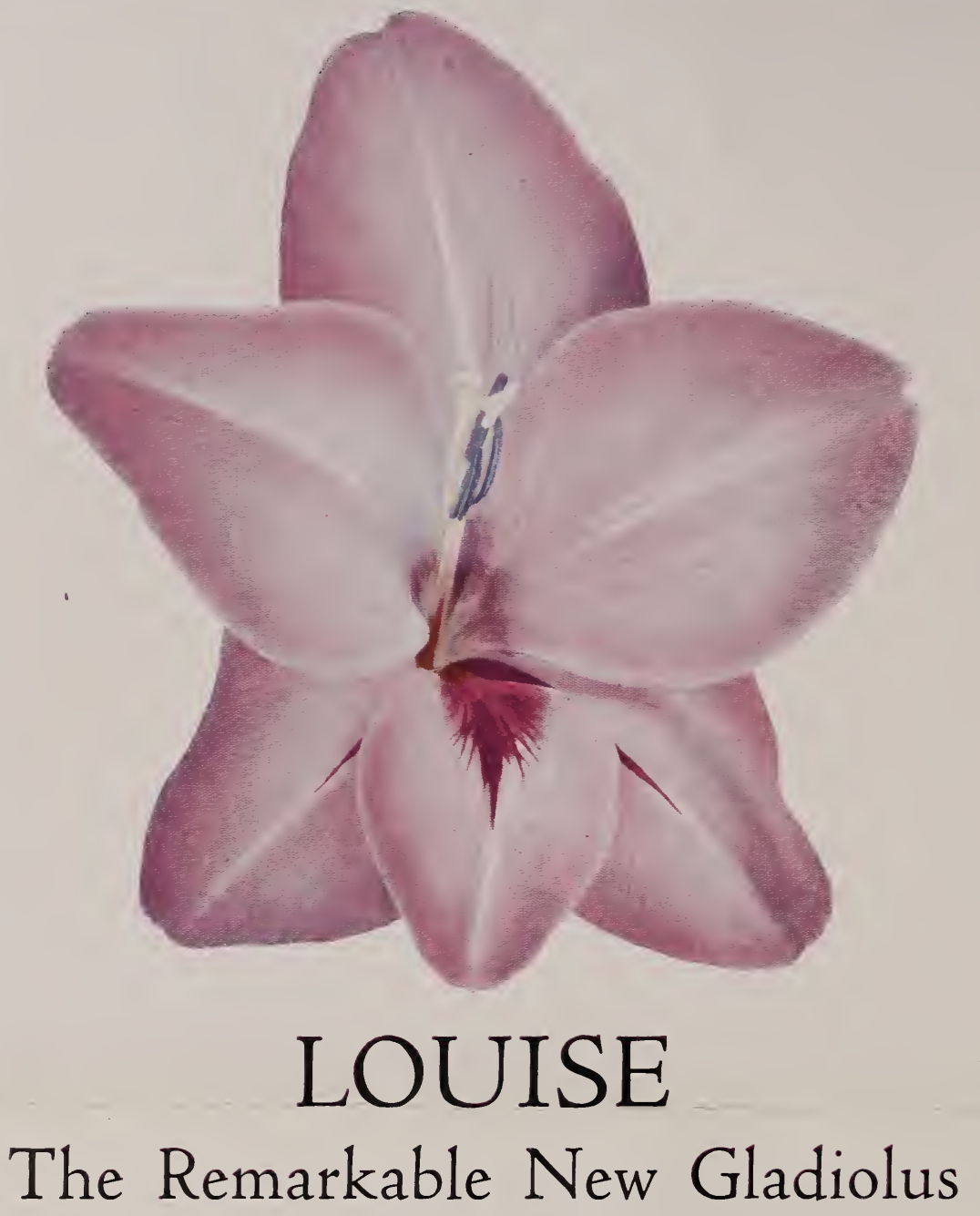

$\mathrm{F}$

OR the season of 1920 we have a new Gladiolus which will be welcomed by flower-lovers all over the country. No matter what varieties you grow now, no matter which you believe the best of their respective classes, we are confident that Louise will more than hold its own. It is, in truth, a super-gladiolus, perhaps the first of a new class of giant gladioli.

Size. Imagine, if you can, blooms which frequently measure 6 to $61 / 2$ inches or more across. Louise, we believe, is the largest gladiolus ever introduced, and it is so remarkable in this respect that this quality alone would be enough to make it popular.

Color. The petals are a delicate shade of bright lavender growing even lighter toward the center of the flower. The blotch of velvety maroon down the center of the lower petal is rendered even more distinctive by a darker line which runs through the center of this blotch.
Growth. Too often gladioli of special merit develop well only under favorable conditions - the temperature must be favorable, the soil not too dry, etc., or the growth is puny and not representative. Louise is a strong grower under almost all conditions; it is able to endure long periods of dry weather, and blooms weIl even in the hottest, driest weather. The stem growth is always sturdy.

Germination. Louise multiplies freely and the bulblets germinate unusually well. You will be surprised at the number of corms obtainable.

Louise is of the type generally known as orchid-like, and the resemblance is quite marked in this flower because of the shape and color.

It blooms well in water, and will last several days longer than most varieties. You really must grow it to properly appreciate it. It is so distinctive that it stands almost alone.

Prices for this remarkable new Gladiolus are as follows:

1 -inch bulbs and over, $\$ 1$ each, $\$ 10$ per doz., $\$ 50$ per 100

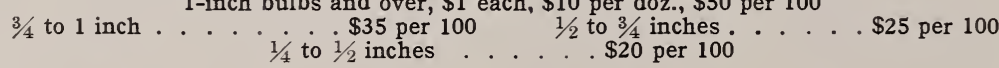

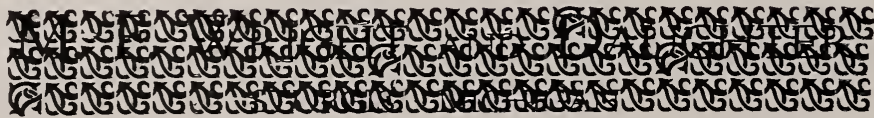




\section{SUPPLEIIENT FOR 1921.}

As I shall not issue a new catalog for the seascn of 1920-21 I give herewith a Supplement, embodying some changes in Price and some Additions of New Varieties, not offered in my 1920 list.

The prices here given will supersede those in the catalog. Where prices of a single bulb are given it is generally to be understood that the dozen price is 10 times the single price.

\section{Changes in Price.}

Augusta ......6c Burrell ......10c Elizabeth Kurtz .......15c straight

Pink Beauty ...8c . Prince of Wales ....15c Qu€€n Wilhelmina, sold out. Pink Perfection..15c Schwaben .....12c

\section{Diener Varieties.}

Elizabeth Gerberding [189] .......15c

Anna Eberius [No. 10] ..........20

Thos. T. Kent [No. 130] .........25c

Mrs. Wm. Kent [No. 1] ........25c

Myrtle McNally [19] ........ Y...

San Anselmo $[22] \ldots \ldots \ldots \ldots \ldots \ldots 25 \mathrm{c}$

Mary S. Burke $[188] \ldots \ldots \ldots \ldots \ldots . .50 \mathrm{c}$

Ross Valley [198] ..............15c

$\$ 2.00$ doz.

$2.50 \mathrm{doz}$.

$2.50 \mathrm{doz}$.

zoridoz.

2.50 doz.

$5.00 \mathrm{doz}$.

1.25 doz.

Mrs. John R. Walsh . ..\$1.50 small bulb . . \$1.00

Diener's Hybrids-[Many as good as named sorts] Large bulbs $\$ 1.75$ doz. $\$ 14.00$ per 100 .

Medium size bulbs $\$ 1.00$ doz. $\$ 7.50$ per 100 .

\section{Additional Diener's.}

Jack London [38]-Light salmon and brilliant orange; yellow throat [I condense] "Our best commercial variety-rapid propagator." 50c.

Mary R. Reinhart [162]-Cream yellow with canary yellow center. $20 \mathrm{c}$.

Diener's White [166]-Again for sale but scarce. Milk white with faint tinge of pink [Gold Medal at P. P. I. E.] Medium bulb $\$ 2.50$; small blooming bulb $\$ 1.50$.

Yaud Fay [176]-Cattleya pink, light strip thro middle of each petal; flowers very open and large, spikes curved; "one of our finest" heavy propagator $50 \mathrm{c}$.

Lillian Webb-Strawberry pink; slightly striped chocolate; curious; erect stems $5 \mathrm{c}$.

Irs. H. E. Bothin [191]-Flesh-salmon pink, flame scarlet center; "A great improvement on Pendleton." 50c.

Frank J. Symmes [204]-Salmon rose pink, red center, ruffled; fine $25 \mathrm{c}$.

Kentfield [210]-Similar to Mary Stearns Burke. 25c. other Added Sorts.

Crimson Glow [Betscher]-Called by some finest red $60 \mathrm{c}$.

Flora-New yellow. Finest except Golden Measure and best at popular price; sold wholesale last year at $75 \mathrm{c}$ to $\$ 2.00$. Special cut price $50 \mathrm{c}$.

Glory of Kennemerland-New giant rose, with small yellow throat; big as Princeps foc.

Le Marechal Foch-New pink from Holland; the sensation of the year. "Twice as large as America, a shade brighter. As early as Halley." Good bulbs grown in America 60c.

Lilywhite [Kunderd] - "The long desired spotless white gladiolus that will bloom well without special care, vigorous in growth and extremely early." [I abridge description.] Highest commendations from many sources $40 \mathrm{c}$.

LImmaculce-Pure white, long spike, gandavensis form, many open at once; early $15 \mathrm{c}$.

Louise-Remarkable large flowers, frequently 6 inches diameter, bright lavender, lighter towards center; blotch of velvety maroon down the center of lower petal, with darker line. Strong grower $50 \mathrm{c}$ to $\$ 1.00$. [See colored plate.]

Grenadier-Large flower and spike; rich scarlet. Similar to Velvet King 10c.

Mary Fennell [Kunderd]-Exquisite lavender with yellow shade in center. Buy it $15 \mathrm{c}$.

Mohonk-Old but rare Childsi, similar to Mrs. Fryer $10 \mathrm{c}$.

Pride of Hillegom-Dazzling scarlet $30 \mathrm{c}$.

Summer-Fine mauve, dotted darker $15 \mathrm{c}$.

The King-Purple magenta, maroon and yellow blotch; a darker Rosella; robust $15 \mathrm{c}$.

White America [Childsi]--Seedling of America, with same habit of growth and form of flower. Color, bud flesh white, opening clear white with small marks of blue in throat. 20c, $\$ 2$ doz. $\$ 15$ per 100 .

Wilhrink-Pink sport of Halley, large and early. $10 \mathrm{c}$

Now I have probably forgctten something but if you see any sort advertised, ask for it and I may have a few of it.

Remember: These prices are "delivered" not f. o. b. somewhere else or Independence. Six at doz. price [ 3 of high-priced sorts] 25 at hundred price.

\section{Seo. S. Woodruff}

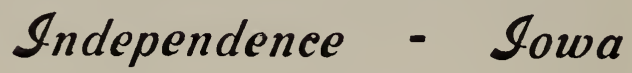



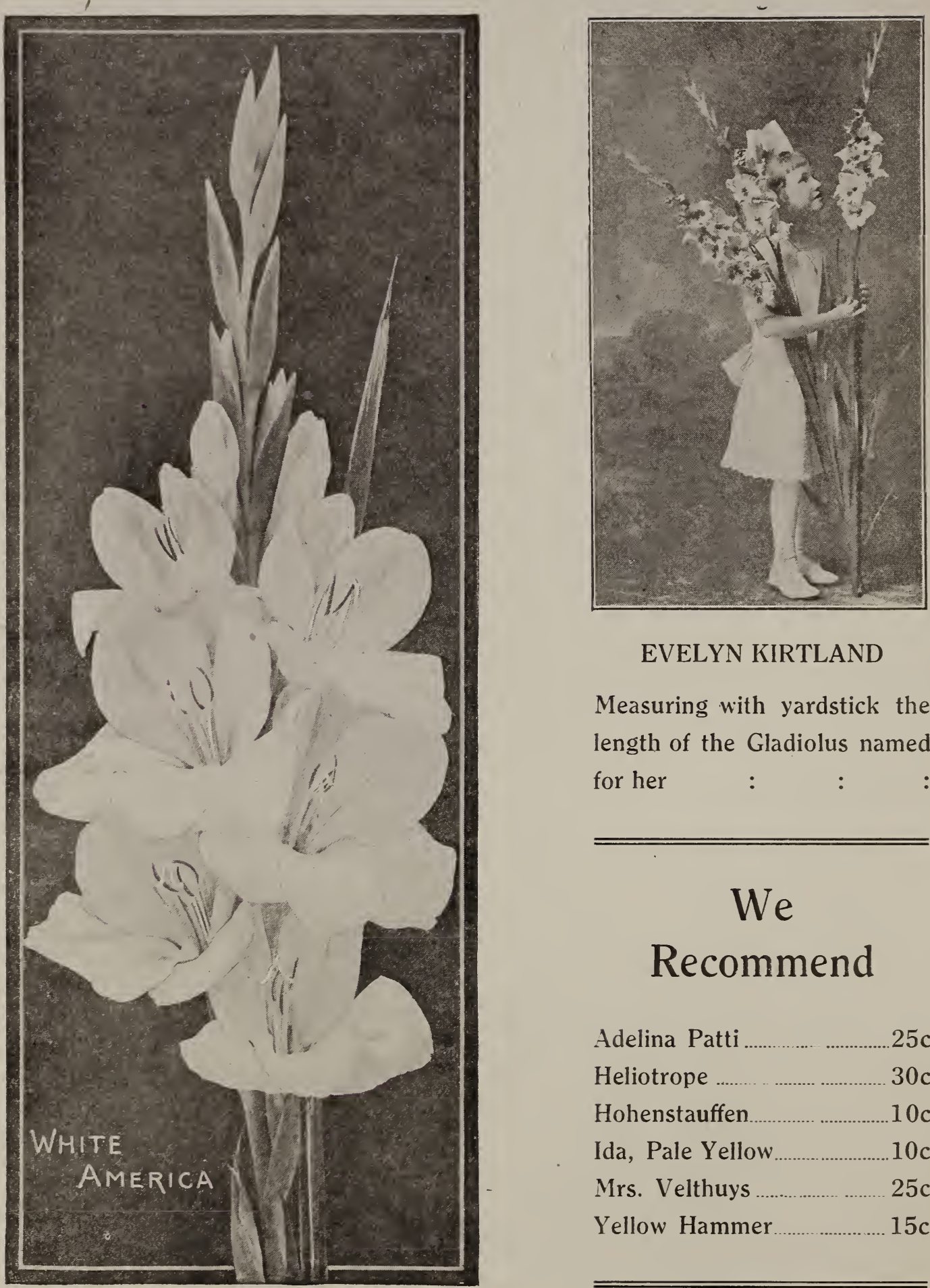

\section{EVELYN KIRTLAND}

Measuring with yardstick the length of the Gladiolus named for her

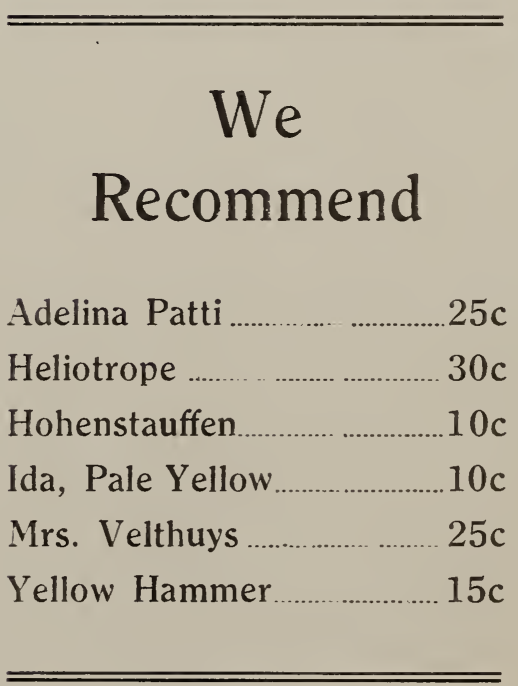


Dr. L. Cothran-(No. 39) Salmon-pink, blue striped. Yellow throat, $25 \mathrm{c}$.

John I. Coulter-(82) Extra fine, rich dark shades; long spike, $25 \mathrm{c}$.

Caroline F. Burke-(No 90) Pure white; ruby throat, big flowers; tall spike, $25 \mathrm{c}$.

Costa Rica-(No. 187) Clear delicate lilac and old rose large, tall $25 \mathrm{c}$.

Elizabeth Gerberding-(No. 189) Shell pink, speckled center of ruby and yellow. Heavily ruffled. First rate, 20c.

Jonathan Webb-(No. 193) Grand sort. Light scarlet finely painted white, and maroon mottled center. Very showy. Lily-like spike with wide open flower's. Very large, 25c.

Helen Todd-(No. 196) Light pink with deep color round edge of flower. Deep scarlet center. Big flowers; long spike, $15 \mathrm{c}$.

Ross Valley-(No. 198) Salmon pink, striped red peacock eye, $25 \mathrm{c}$.

Mrs. John R. Walsh-(No. 202) Here we have the grandest thing. Flesh pink, flame colored center. Flowers five inches diameter, stems five feet tall. Ruffied. A seedling of Mrs. Pendleton. Price reduced from $\$ 5.00$ to $\$ 3.00$ each.

Sir Roger-(No. 203) Dark maroon, heavily ruffled. Long spike, flowers medium, large, 25c. price.

The price of a dozen is 10 times the single

\section{Diener's Fancy Seedlings.}

These are the unnamed seedlings which I have tried for two years. While they vary considerably, they were, under fairly favorable conditions, most remarkable in size and variety, especiaily in light colors. Often five and a half feet high. Some of them were as fine as any of the named sorts and I would glady have paid $\$ 1.00$ apiece for them if I could have known which they were.

The Diener Co. offer only one mixture this year and the price is $\$ 2.00$ per doz., or $\$ 15$ per hundred.

\section{THE FLOWER GROWER.}

I recommend The Flower Grower to all my customers and all interested in growing flowers. Published monthly by Madison Cooper, Calcium, N. Y., handsomely printed and illustrated and has a good list of practical contributors. Subscription price $\$ 1.00$ per year or 3 years for $\$ 2.00$. I will forward subscriptios on receipt of price and will give as a premium 20 selected gladiolus bulbs.

\section{SOME GARDEY SEEDS.}

I am not in the seed business, but a few things I have found especially good and offer seed, either of my own selecting or headquarters seed.

John Baer Tomato- "Earliest and best tomato on Earth." Large, beautiful, solid tomatoes in 30 days from strong plants grown in pots or bands; fruit smooth, solid, few seeds, finest flavor, ripens up to the stem. Very uniform size. Does not run to vines excessively, but better be staked. Packet 10c.

Tomato, New Glory-Another "best" variety. Not quite so early as John Baer, but very prolific, perfect shape, an abundant and continuous bearer. Blight proof when many crops were ruined. Packet $25 \mathrm{c}$, about 200 seeds; $1 / 2$ oz. $\$ 1.50 ; 1$ oz. $\$ 2.50$.

Redhead-Tried this on small scale. Started the plant searly in 3 and 4 inch pots and they certainly did well. Fruit was solid and kept coming until late. Perhaps not quite as smooth as John Baer but certainly excellent. I paid $15 \mathrm{c}$ for about 100 seeds and was satisfied. Seed of my own growing $10 \mathrm{c}$ packet.

"Mighty Nice"-Beans (Bolgiano's). An extra fine, wonderfully prolific green-podded snap bean. Also excellent as dry beans. Packet 10c, pt. $30 \mathrm{c}$.

\section{GEO. S. WOODRUFF}




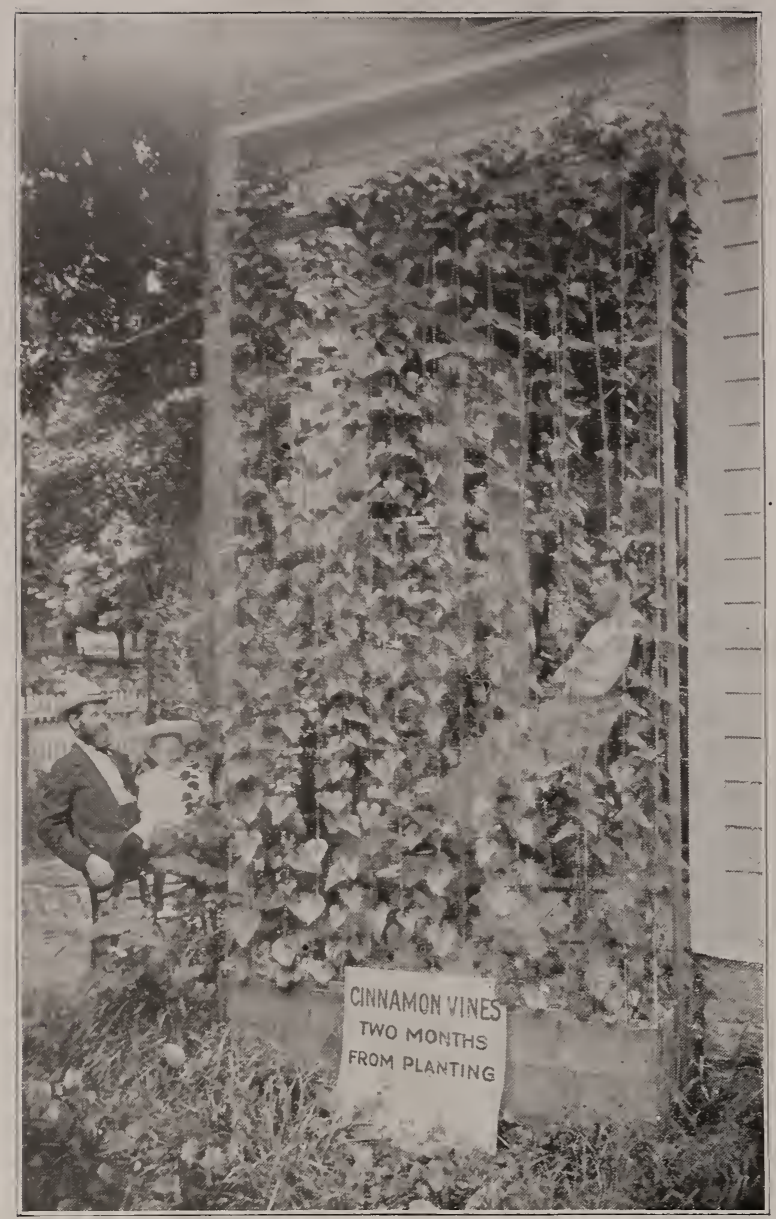

\section{CHINESE CINNAMON VINE}

The Cinnamon Tine (Dinscorea), an old favorite in some places, but almost forgotten. is a charming and very rapid growing climber, takingits name from the delicate white flowers. The growth is remarkably rapid, often running 2.5 to 40 feet in one season. The leaves are heart shaped, kright, glossy green. and the vine produces small tubers at the axils of the leaves. Once planted they last a lifetime.

Plant any time from earliest spring to July 15.

FIVE SELECTED TUBERS carefully packed and sent post paid for 2j̃c.

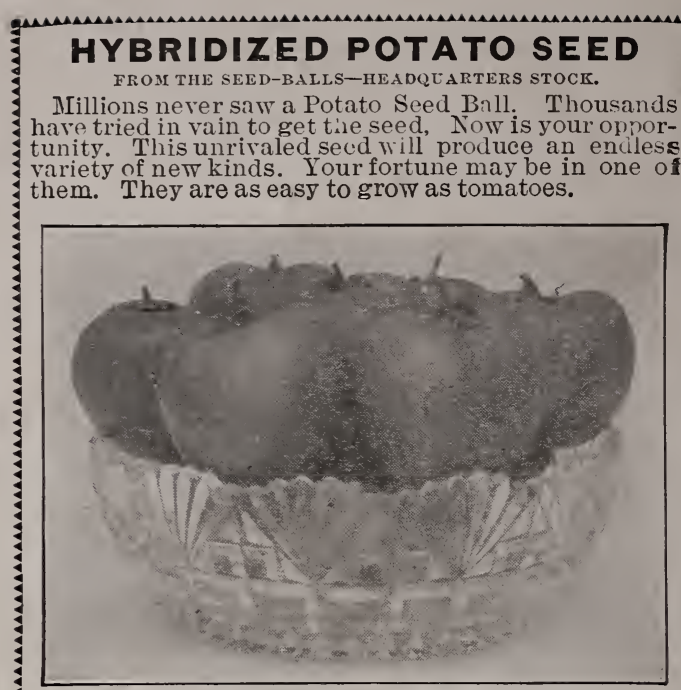

PHOTO OF POTATO SEFD BALLS-ONE-HALF NATURAL SIZE. IT It is from these that ALL valuable new varieties of Potatoes are produced.

Growing new and distinct Seedling Potatoes from the Seed-Ball Seed is intemsely interesting. They will be the griatest curiosity of your garden. This seed will positively produce innumerable $n$ "w kinds, color's, shapes, sizes, and qualities. The p:oduct .Il astonish you. Some may be of immense value and bring you a golden harvest. Every farmer, garlener, and bri, boy should plant a for packets. You may be one of the lucky ones. Full directions on every packet.

READ THESE EXTRACTS FROM CLSTOMERS LETTERS. ". I grew 101 Potatoes from one plant of your Potato Seed. Every plant was a difierent variety."

"I raised 50 IIills from one Packet; many kinds and colors; some early, sulue late. 94 Potatoes in one hill."

"Your remarkable Potato Seed prodnced white, pink, red, wurple, blue, cream, russet, and black potatoes." W. M.Johnson. "Your Potato Seed is a wonder. I grew 115 different varieties "Your Potato Seed is a wonder. I grew 115 different varieties
from one Pacset-tive finest I ever saw." "I grew 45 pounds of Seedling Potatoes from one Packet. I expect wonders from them next year."

Packet 15 cts. 2 for 25 c. 5 for 50 c. 10 for $\$ 1$.

\section{Other Varieties of Gladioli}

I have small lots of many varieties of gladioli not listed here, of which, I have too few to catalog. If you see in other catalogs, varieties which you would like to have, ask for them, and I may have them or if not, can often get them for you, and sometimes at less cost than elsewhere.

\section{Mistakes}

In all the different processes, from planting thru digging, storing, cleaning, etc., by different hands, it is inevitable that some mistakes will occur. I go through the fields daily, during the blooming period and "rogue" out all I find that are out of their own row, but the process can not be complete. I will cheerfully correct such mistakes when notified. "If satisfied, tell your neighbors; if not, tell me."

\section{GEO. S. WOODRUFF}

